\title{
STRATEGI PENINGKATAN KAPASITAS PENGELOLA WISATA PANTAI BERBASIS PELATIHAN (STUDI KASUS PADA KELOMPOK POKDARWIS MELKA DESA MALAKA) KABUPATEN LOMBOK UTARA
}

\author{
SULAEMAN \\ Fakultas Budaya Manajemen dan Bisnis Undikma Mataram \\ E-mail : yazid.emen@gmail.com
}

\begin{abstract}
ABSTRAK
Penelitian ini mengkaji tentang strategi pengembangan sumber daya manusia di Bidang Pariwisata dikaji dari sudut pandang peningkatan kapasitas pengelola wiata daerah pesisir (wisata pantai). Keberadaan SDM khususnya Anggota Pokdarwis Melka Desa Malaka memegang peranan penting dalam pengelolaan dan pengembagan Obyek wisata pantai khususnya pantai pandana, namun pengelolaan wisata pantai pandanan saat ini mmasih belum maksimal dikelola dengan baik, hal ini disebabkan karena masih minimnya pengetahuan anggota pokdarwis seklaku pengelola obyek wisata terkait dengan ekosisstem terumbu karang yang ada yang mmerupakan obyek andalan dan tujuan bagai wisatawan yang berwisata di pantai Pandanan. Berdasarkan masalah yang dihadapi, maka penelitian ini bertujuan untuk mengkaji peran pelatihan bagi anggota pokdarwis Melka Kabupaten Lombok Utara khusunya terkait dengan pelatihan Pengenalan ekosistem terumbu karang for Guiding serta mekanismme promosi obyek wisata Pantai Pandanan berbasis media online. Keberadaan SDM pengelola obyek wisata berperanan penting dalam pengembangan pariwisata. SDM pariwisata mencakup wisatawan/pelaku wisata (tourist) atau sebagai pekerja (employment). Penelitian ini menggunakan pendekatan kualitatif, yaitu pendekatan yang bersifat induktif. Jenis penelitian ini dikategorikan kedalam penelitian deskriptif. Hasil penelitian menunjukkan bahwa kegiatan pelatihan bagi anggota Pokdarwis khususnya pelatihan terkait ekosistem terumbu karang, sangat berperan penting dalam peningkatan kapasitas pengetahuan dari pengelola obyek wisata pantai pandanan sehingga Anggota Pokdarwis selaku pengelola obyek wisata pantai yang ada, dapat merumuskan strategi pengelolaan dan pengebangan obyek wisata pantai yang berwawasan lingkungan, dengan harapan obyek wisata plantai pandanan dapat berkembang dengan tetap terjaga kelestarian ekosistem nya. Pelatihan ini juga dapat memberikan peningkatan pengetahuan bagi pengelola wisata dalam peningktan kapasaitas memiliki keunggulan kompetitif, handal serta efektif dan efisien.
\end{abstract}

Kata kunci: Obyek wisata pantai, Pokdarwis Melka, Pelatihan ekosistem karang

\section{LATAR BELAKANG}

Potensi wisata yang dimiliki Provinsi NusaTenggara Barat khususnya Kabupaten Lombok Utara sangat beraneka ragam, keanekaragaman budaya dan keindahan alam sangat berpotensi untuk terus dikembangkan. Upaya pengembangan obyekwisata yang ada menjadi suatu alternative dalam upaya peningkatan keterlibatan atau partisipasimasyarakat dalam pengembangan sektor wisataterutama pemuda. Dalam pengembangan obyek wisata menjadi penting guna mendorong terciptanya segmen pasar wisatawan yang enginginkan keunikan produk masing masing obyek wisata satu dengan obyek wisata lainnya

Dibeberapa daerah, termasuk di Kabupaten Lombok Utara. Pengembangan dan peningkatan skill kapsitas pengelola obyek wisata dana kepariwisatan masih minim dan belum maksimal dijalankan. Dapat dikatakan juga bahwa dalam proses perencanaan dan pengembangan kepariwisataan, pembahasan tentang SDM yang dibutuhkan dalam pelayanan kegiatan kepariwisataan yang benar dan efektif seringkali mendapat perhatian yang rendah. Dalam beberapa kasus, bahkan sama sekali diabaikan. Hal tersebut mengakibatkan timbulnya permasalahan serius dalam industri kepariwisataan, dan memungkinkan terhalangnya partisipasi masyarakat setempat dalam kegiatan ekonomi yang dikembangkan dari 
pengembangan kepariwisataan. Padahal dengan potensi yang dimilikinya,pengembangan obyek wisata sangat diperlukan agar dapat bersaing dengan wahana dan media wisata yang ada, adapun berbagai potensi wisata yang dimiliki di kabupaten Lombok Utara antara lain berbagai potensi alam yang dimiliki,meliputi bukit dan pantai melimbu, gugusan pulauberupa gili matra (gili air, meno dan trawangan)yang sudah mendunia, hutan wisata pusuk, airterjun sendang gile dan Tiu kelep, Pelawangan, Senaru Gunung Rinjani, kampung ekowisatakerujuk, pantai Impos, Desa Adat Dusun Beleq Gumantar dan Pantai Pandanan dan Pantai Nipah.

Desa Malaka merupakan merupakan salah satu desa diantara 3 (tiga) Desa lainnya yang ada di Kecamatan Pemenang, jumlah penduduk di desa ini adalah 101,07 jiwa dengan 4551 Laki-laki dan 4503 perempuan,dengan komposisi penduduk didominasi oleh kalangan usia muda usia 15 tahun sampai 39 tahun dengan jumlah penduduk 5047 jiwa yang menetap di desa engan luas desa ini sekitar 12,41 km dengan 12 dusun, keberadaan obyek wisata pantai pandanan didukung dengan tersedianya fasilitas wisata yang sudah ada dengan beroperasinya 12 hotel sebagai wadah tempat menginap dan singgah para wisatawan yang berwisata di desa Malaka dan sekitarnya.

Pantai Pandanan merupakan salah satu obyek wisata unggulan d Nusa Tenggara Barat, khusunya Pulau Lombok. Hal ini tercermin dari tersedianya berbagai macam wahana wisata yang ada, khususnya wisata bahari dengan keindahan terumbu karang dan tersedianya tersedianya berbagai jenis spot diantaranya adalah adanya spot kegiatan snorkel dengan berbagai jenis terumbu karang yang dimiliki, dibarengi dengan ketersedian ratusan jenis ikan karang yang beraneka warna warni, spot permainan cano, spot banana boat, spot memancing dan area mandi. Selain spot tersebut, pantai pandanan juga sudah familiar dengan berbagai macam kuliner yang dijajakan oleh masyarakat dan pemuda yang menekuni bisnis kuliner, kuliner yang palng tersohor di obyek wisata ini adalah kelezatan ikan bakar yang dimilikinya.

Berbagai jenis keunggulan obyek wisata yang dimiliki oleh pantai ini, menjadikan pantai ini harus bener benar dikelola dan adanya upaya pengebangan dalam pengelolaannya, sehingga menjadi tujuan wisata utama sehingga obyek wisata pantai pandanan ini terus dapat bersaing dengan obyek wisata utama lainnya di Kabupaten Lombok Utara khususnya dan Nusa Tenggara Barat secara menyeluruh. Untuk mewujudkan hal tersebut, sangat membutuhkan keterlibatan semua pihak untuk mengelolanya serta pengemmbangannya, terutama para pemuda yang ada di Desa Malaka

Partisipasi seluruh elemen masyarakat selain pemuda termasuk masyarakat lokal dalam pelibatan pangembangan pariwisata adalah penting adanya. Hal ini tertera dalam Peraturan Pemerintah Republik Indonesia Nomor 50 tahun 2011 tentang Rencana induk pembangunan kepariwisataan nasional Tahun 2010 - 2025, yang menyebutkan "Pemberdayaan Masyarakat adalah upaya untuk meningkatkan kesadaran, kapasitas, akses, dan peran masyarakat, baik secara individu maupun kelompok, dalam memajukan kualitas hidup, kemandirian, dan kesejahteraan melalui kegiatan Kepariwisataan.” Pemuda sebagai bagian dari masyarakat lokal pastinya juga harus diikutsertakan dalam pengembangan pariwisata. (Swasono, 2013).

Permasalahan yang dihadapi oleh pengelola pantai pandanan, dalam hal ini Anggota dari Pokdarwis Melka selaku penanggung jawab dalam pengelolaan dan pengembangan obyek wisata pantai pandanan adalah masih minimnya SDM dengan pengetahuan yang mumpuni terkait dengan pengetahuan ekosistem terumbu karang serta mekanisme pemanfaatannya termasuk proram promosinya.

Adanya keterbatasan pengeatahuan dan kemampuan Anggota Pokdarwis terkait dengan pemahaman mengenai ekosistem terumbu karang, menyebabkan organiasai harus mencari solusi alternative dalam meningkatkan skill anggota yang dimiliki, sehingga pengelolaan dan pengembangan potensi wisata bahari dapat dirumuskan dan dijlankan sesuai dengan rencana dan standar yang ada. Melihat manajemen pengelolaan obyek wisata pantai pandanan yang belum memiliki sumber daya manusia yang handal dalam hal pengelolaan obyek wisata pantainya, maka peneliti bermaksud untuk meneliti terkait dengan Strategi peningkatan 
kapasitas pengelola wisata pantai berbasis pelatihan (Studi kasus pada Kelompok Pokdarwis Melka Desa Malaka) Kabupaten Lombok Utara

\section{TINJAUAN PUSTAKA}

\section{a. Pengertian Manajemen Sumber Daya Manusia}

Dalam suatu organisasi hal yang paling penting yang perlu diperhatikan adalah sumber daya manuisa yang menjadi pendukung utama tercapai tujuan organisasi. Sumber daya manusia menempati posisi strategis dalam suatu organisasi, maka dari itu sumber daya manusia harus digerakkan secara efektif dan efisien sehingga mempunyai tingkat hasil daya guna yang tinggi. Manajemen SDM adalah rangkaian strategis, proses dan aktivitas yang di desain untuk menunjang tujuan perusahaan dengan cara mengintegrasikan kebutuhan perusahaan dan individunya (Rivai, 2015).

Adapun Dessler (2011) mendefinisikan manajemen sumber daya manusia sebagai kebijakan dan praktik menentukan aspek manusia atau sumber daya manusia dalam posisi manajemen, termasuk merekrut, menyaring, melatih, memberi penghargaan dan penilaian. Sedangkan menurut Umar (2008) Manajemen Sumber Daya Manusia adalah suatu perencanaan, pengorganisasian, dalam penggerakan dan pengawasan atas pengadaan, pengembangan, kompensasi, pengintegrasian pemeliharaan, dan pemutusan hubungan kerja dengan maksud untuk pencapaian tujuan organisasi perusahaan secara terpadu.

Dari beberapa pendapat diatas, dapat menarik kesimpulan bahwa manajemen sumber daya manusia merupakan ilmu dan seni yang di dalamnya terkandung fungsi - fungsi manajerial dan operasional yang ditujukan agar sumber daya manusia dapat dimanfaatkan seefektif dan seefisien mungkin untuk mencapai sasaran yang ditetapkan. Dengan perencanaan sumber daya manusia dapat menentukan kebutuhan akan tenaga kerja berdasarkan peramalan, pengembangan, pengimplementasian, dan pengontrolan kebutuhan tersebut yang berintegrasi dengan rencana organisasi agar tercipta jumlah pegawai, penempata pegawai secara tepat dan bermanfaat secara ekonomis.

\section{b. Pelatihan}

Pelatihan adalah suatu proses pendidikan jangka pendek memanfaatkan prosedur yang sistematis dan terorganisir, dimana personil non manajerial mempelajari kemampuan dan pengetahuan teknis untuk tujuan tertentu. Pelatihan adalah bagian dari pendidikan menyangkut proses belajar untuk memperoleh dan meningkatkan ketrampilan di luar sistem pendidikan yang berlaku, dalam waktu yang relatif singkat dan dengan metode yang lebih mengutamakan praktek dari pada teori. Pelatihan atau training adalah proses sistematis pengubahan tingkah laku para karyawan dalam suatu arah untuk meningkatkan pengetahuan dan keterampilan seorang pegawai atau tenaga kerja dalam melaksanakan tugas atau pekerjaan tertentu (Masud dan Flipo, 1995)

\section{c. Tujuan serta Manfaat Pelatihan}

Menurut Tylon (2013) terdapat beberapa tujuan serta manfaat pelatihan baik yang dirasakan oleh pegawai maupun bagi organisasi. Diantaranya adalah:

Tujuan utama dari pelatihan ini adalah untuk mengatasi kekurangan-kekurangan para sumber daya manusia dalam bekerja yang disebabkan oleh kemungkinan ketidakmampuan dalam pelaksanaan pekerjaan, memutakhirkan keahlian para karyawan sejalan dengan kemajuan teknologi, mengurangi waktu belajar bagi karyawan baru supaya menjadi kompeten dalam pekerjaannya, membantu memecahkan permasalahan operasional, memenuhi kebutuhan-kebutuhan perkembangan pribadi, mempersiapkan karyawan untuk promosi dan sekaligus berupaya membina mereka agar menjadi lebih produktif .

Selain yang dipaparkan di atas ada beberapa tujuan pelatihan dan pengembangan SDM dalam sebuah organisasi:

1. Untuk mengurangi gap atau perbedaan kinerja yang ada antara hasil yang diinginkan dengan apa yang dicapai oleh pegawai sebagai akibat ketidakmampuan pegawai untuk 
mancapai standar yang ditetapkan. Pelatihan untuk meningkatkan kinerja ini penting bagi organisasi yang sedang mengalami penurunan produktivitas

2. Terkait dengan perkembangan teknologi, pelatihan dan pengembangan membuat pegawai lebih produktif dan lebih adaptif. Hal ini secara langsung akan membuat organisasi lebih adaftif pula sehingga akan meningkatkan kemampuan dan keuntungan organisasi

3. Meningkatkan komitmen dan persepsi pegawai terhadap organisasi

Disamping tujuan tersebut, ada beberapa manfaat yang dapat dirasakan baik bagi pegawai maupun organisasi. Diantaranya:

1) Manfaat bagi organisasi

a) Peningkatan produktivitas kerja organisasi

b) Terwujudnya hubungan serasi antara atasan dan bawahan

c) Proses pengambilan keputusan lebih cepat dan tepat

d) Meningkatkan semangat kerja seluruh tenaga kerja dalam organisasi dengan komitmen organisasional yang lebih tinggi

e) Mendorong sikap keterbukaan manajemen

f) Memperlancar jalannya komunikasi yang efektif

g) Menyelesaikan konflik secara fungsional

2) Manfaat bagi pegawai

a) Membantu membuat keputusan dengan lebih baik

b) Meningkatkan kemampuan dalam menyelesaikan berbagai masalah yang dihadapi

c) Terjadinya internalisasi dan operasionalisasi factor-faktor motivasional

d) Menimbulkan dorongan untuk terus meningkatkan kemampuan

e) Meningkatkan kemampuan untuk mengurangi stress, frustasi, dan konflik, sehingga akan memperbesar rasa percaya diri

f) Memanfaatkan informasi tentang berbagai program yang dapat meningkatkan kemampuan teknikal dan intelektual

g) Meningkatkan kepuasan kerja

h) Meningkatkan pengakuan atas kemampuan seseorang

\section{d. Tahap-tahap Pelatihan}

Menurut Sedarmayanti dan Safer (2016) Program pelatihan mempunyai tiga tahap aktivitas yang mencakup:

1. Penilaian kebutuhan pelatihan (need assasment), yang bertujuan mengumpulkan informasi untuk menentukan dibutuhkan atau tidaknya program pelatihan

2. Pengembangan program pelatihan (development), bertujuan untuk merancang lingkungan pelatihan dan metode-metode pelatihan yang dibutuhkan guna mencapai tujuan pelatihan

3. Evaluasi program pelatiahan (evaluation) yang mempunyai tujuan untuk menguji dan menilai apakah program-program yang telah dijalani, secara efektif mampu mencapai tujuan yang telah ditetapkan

Penyusunan progam pelatihan dan pengembangan, sesuai dengan tujuan yang akan diwujudkan, harus dilakukan dengan mengikuti langkah tertentu dan sistematis. Langkah pengorganisasian program pelatihan dan pengembangan antara lain:

1. Melakukan penelitian dan pengumpulan data tentang aspek obyek yang akan dikembangkan

2. Menentukan metode pelatihan dan pengembangan

3. Memilih pelatih sesuai kebutuhan

4. Mempersiapkan fasilitas yang dibutuhkan

5. Memilih peserta

6. Melaksanakan program

7. Melakukan evaluasi program 


\section{e. Konsep Pariwisata}

Umumnya pariwisata memiliki konsep yangsangat luas, konsep ilmu kepariwisataan menurut Kusmayadi (2000) merupakan suatu kegiatan melakukan perjalanan dari rumah dengan maksud tidak melakukan usaha atau bersantai. Pariwisata di wilayah pedesaan saat ini menjadi salah satu alternative yang memiliki daya tarik tersendiri dalam kepariwisataan. Kehidupan pedesaan yang memiliki ciri khusus pada masyarakat, alam dan budayanya menjadi suatu komoditi bagiwisatawan (Hadiwijoyo, 2012).

Pembangunan pariwisata selayaknya tidaklah mengabaikan manfaat yang diterima masyarakat lokal. Masyarakat perlu diberdayakan sebagaipihak yang memiliki Pemberdayaan dapat dilakukan melalui penyadaran kemampuan (enabling), penguatan potensi (empowering) dan kemandirian (autonomy). Tujuannya agar masyarakat local dapat menjadi pelaku aktif dalam kegiatan pariwisata dan pengembangannya. Mereka juga dapat memiliki tanggung jawab moral yang tinggi dalam pemanfaatan sumberdaya yang mereka miliki, karena mereka menyadari bahwasanya keberadaan sumberdaya akan mempengaruhi kehidupan mereka (Pitana, 1999).

\section{METODE PENELITIAN}

Dalam penelitian ini, peneliti menggunakan pendekatan kualitatif, yaitu pendekatan yang bersifat induktif. Berdasarkan tujuan penelitian, jenis penelitian ini dikategorikan kedalam penelitian deskriptif. Hasil dari penelitian deskriptif adalah gambaran yang jelas mengenai subjek penelitian (Neuman, 2000). Berdasarkan manfaatnya, penelitian ini merupakan penelitian murni. Berdasarkan dimensi waktunya, penelitian ini merupakan penelitian crosssectional.

Berdasarkan teknik pengumpulan data, maka penelitian ini termasuk dalam penelitian kualitatif. Peneliti menggunakan wawancara mendalam dan studi kepustakaan sebagai instrumen pengumpulan data. Data yang diperoleh pada saat penelitian dibagi menjadi data primer dan data sekunder. Teknik pengumpulan data yang digunakan dalam penelitian ini adalah teknik pengumpulan data kualitatif yang berupa studi lapangan (field research) dan studi kepustakaan (library research). Kedua teknik pengumpulan data tersebut dalam rangka memperoleh data primer dan sekunder yang lebih komprehensif dan mendalam mengenai permasalahan yang diangkat penulis. Pemilihan lokasi dalam penelitian ini dilakukan di tempat yang dapat mendukung penelitian dan relevan dengan permasalahan yang diteliti. Dalam penelitian ini, lokasi penelitian adalah Pantai Pandanan Desa Malaka, khususnya Pokdarwis Melka serta kantor pihak-pihak yang memiliki kapasitas dalam pengembangan obyek wisata Pantai Pandanan Desa Malaka.

\section{HASIL PENELTIAN DAN PEMBAHASAN}

Berdasarkan wawancara mendalam dengan narasumber dalam hal ini ketua kelompok Pokdarwi Melka, didapatkan bahwa kegiatan pelatihan bagi anggota dan pengurus Pokdarwis Melka Desa Malaka memiliki peranan yang sangat strategis, karena dengan kegiatan pelatihan ini dapat meningkatkan Kemampuan skill dan kapasitas anggota Dalam Pengembangan Kawasan Wisata khususnya obyek wisata pantai pandanan, karena pada dasarnya SDM Pokdarwis Melka adalah unsur terpenting dalam keberhasilan suatu organisasi pokdarwis itu sendiri.

Pandangan senada diungkapkan oleh Susanto (1997) menyatakan bahwa bahwa asset organisasi terpenting dan harus diperhatikan oleh menejeman adalah manusia (sumber daya manusia "human resources"). Hal ini bermuara pada kenyataan dimana manusia merupakan elemen yang selalu ada dalam setiap organisasi. Manusia membuat tujuan-tujuan inovasi dan pencapaian tujuan organisasi. Manusia merupakan satu-satunya sumber daya yang dapat membuat sumber daya organinasi lainnya bekerja dan berdampak langsung terhadap kesejahteraan perusahaan.

Adapun terkait dengan masih minimnya pengetahuan dan skill peneglola obyek wisata Pantai Padanan terkait dengan pengetahuan dala pengembangan obyek wisata pantai, terutama 
berhubugan dengan peanfaatan dan pengelolaan Ekosistem terumbu karang sebagai media wisata selam, snorkel, dan wisata dapat berdampak langsung terhadap pelayanan bagi wisatawan yang ingin focus tertarik dengan wisata pesisir yang dating berkunjung, padahal menurut inforasi yang ada, kawasan wisata pantai pandanan merupakan obyek wisata snorkel, selam yang merupakan kawasan penyokong ekosistem terumbu karang kawasan Gili matra, yaitu Gili Meno, Gili Air dan Gili Trawangan dengan keindahan terubu karang yang begitu eksotis serta kelipahan jenis spesies ikan karangnya.

Permaslahan ini benar benar enjadi perhatian pengelola Pokdarwis Melka untuk terus diselesaikan, dengan menjalin kerjasama dengan berbagai intnasi terkait, baik dari kalangan pemerintahan, mmaupun lembawa pemuda, swasta lainnya, implikasi dari kerjasama yang terbangun adalah Pokdarwis Melka selaku pengelola obyek wisata pantai Pandanan dan obyek wisata sejenis di Desa Malaka baru satu kali berhasil melakukan pelatihan pengetahuan terkait Ekosistem Terumbu Karang bekerjasama dengan Lembaga Lichen Isnstitut yang bersinergi dengan program Pemuda dari Kementrian Pemuda dan Olahraga Republik Indonesia pada Tahun 2019 pasca Bencana Gempa yang melanda Kabupaten Lombok Utara, sebagaimana disampaikan oleh Saudara Zikrurrahman Selaku Ketua Pokdarwis Melka Desa Malaka Kabupaten Lombok Utara.

Pelatihan sejenis sangat diharapkan untuk terus dilaksanakan bagi pengelola wisata pantai, khususnya bagi Pokdarwis Melka Desa Pandanan, dengan adanya rutinitas pelatihan yang diberikan dapat meningkatkan kapasitas skill pengelola obyekwisata sebagai dasar bagi pengelola untuk terus meningkatkan pelayanan yang mereka berikan bagi pengunjung yang datang berkunjung serta sebagai dasar agar dapat terus meningkatkan kapasitas pengelolaan dan pengembangan terhadap obyek wisata pantai yang dikelola agar pengelolaan dapat berjalan dengan ramah lingkungan serta ekosistem pantai yang ada terus lestrasi.

Permasalahan yang dihadapi oleh Pokdarwis Melka merupakan salah satu masalah yang harus terus di minimalisir dan di selesaikan dalam mengembangkan pariwisata, sebagimana diungkapkan oleh Spillane James. J (1994):'Salah satu masalah dalam mengembangkan pariwisata adalah tidak tersedianya fasilitas yang cukup untuk menunjang pendidikan pariwisata. Sumberdaya kerja yang cakap, terampil, memiliki skill tinggi dan pengabdian pada bidangnya(professional) menjadi kebutuhan mutlak dalam bersaing di pasaran global. Produk industri pariwisata adalah "jasa", oleh karena itu penekanannya harus pada segi pelayanan yang disesuaikan dengan kebutuhan wisatawan. Dalam industri pariwisata, kualitas pelayanan merupakan indikator utama yang menunjukkan tingkat professionalnya.

Untuk itu maka dalam pengelolaan dan pengembangan obyek wisata Pantai Pandanan, Pokdarwis Melka harus terus berupaya melakukan pengembangan dan peningkatan kapasitas skilnya dari berbagai bidang pengelolaan, khusunya dalam pengelolaan ekosistem pesisir yang dimiliki, agar dapat tekelola sesuai dengan harapan dan target pengembangan obyek yang direncanakan, sehingga dengan adanya kegiatan pengembangan diri yang terus dilaksanakan, maka sumberdaya yang dimiliki oleh Pokdarwis ini dapat menjadi sumberdaya yang handal dengan kapasitas yang dibutuhkan oleh organisasi. Sehingga sejalan dengan pendapat Djokroaminoto dkk (2001) bahwa pengelola Obyek wisata atau kasawan wisata membutuhkan sumberdaya atau figure yang mumpuni, berupa sosok manusia abad 21 , yang mana sosok sumberdaya manusia pada abad 21 adalah manusia-manusi yang memiliki kualifikasi sebagai berikut : 1. Memiliki wawasan pengetahuan (knowledge), ketrampilan (skill), dan sikap atau perilaku (attitude) yang relevan dan mampu menunjang pencapaian sasaran dan bidang tugas dalam suatu organisasi. 2. Memiliki disiplin kerja, dedikasi dan loyalitas yang tinggi terhadap pekerjaan dan terhadap organisasi. 3. Memilki rasa tanggungjawab dan pengertian atau pemahaman yang mendalam terhadap tugas dan kewajibanya sebagai karyawan atau unsure manajemen organisasi. 4. Memiliki jiwa kemauan yang kuat untuk berprestasi produktif dan bersikap professional. 5. Memilki kemauan dan kemampuan untuk selalu mengembangkan potensi dan kemampuan diri pribadi demi kelancaran pelaksanaan tugas organisasi. 6. Memiliki kemampuan yang tinggi dalam bidang tehnik maupun manajemen dan kepemimpinan. 7 . 
Memiliki keahlian dan ketrampilan yang tertinggi dalam bidang tugas dan memiliki kemampuan alih teknologi. 8. Memiliki jiwa kewirausahaan (enterpreneurship) yang tinggi dan konsisten 9. Memilki pola pikir dan pola tindak yang sesuai dengan visi, misi, dan budaya kerja organisasi.

Berdasarkan pandangan tersebut dapat dijelaskan bahwa Pendidikan kepariwisataan merupakan salah satu kunci dalam mengembangkan potensi kepariwisataan (kawasan wisata), karena bidang ini memerlukan tenaga kerja terampil yang secara terus menerus harus dikembangkan, sehingga pengembangan sumberdaya pengelola obyek wisata pantai pandanan ini dapat terus dilakukan dan dapat mengacu pada 3 pokok utama pengembangan sumberdaya pengelola wisata yaitu 1. Pengembangan pengetahuan tentang tata cara pelayanan yang berkaitan dengan bervariasinya kegiatan pariwisata, misalnya pelayanan di hotel, berbeda dengan pelayanan di tempat rekreasi atau dalam perjalanan wisata. 2. Pengembangan pengetahuan tentang peralatan dan perlengkapan yang diperlukan dalam bidang pelayanan. 3 . Pengembangan SDM yang berkaitan dengan pengembangan sikap, perilaku, sopan santun, dan sebagainya, (Wartiningsih, 2002). Ketiga hal tersebut setiap saat selalu berubah dan mengarah pada kemajuan, sehingga ketiganya harus selalu ditingkatkan khususnya melalui pelatihan yang juga akan mempengaruhi daya serap industry Pariwisata itu sendiri (Setiawan, 2016).

Hal senada diungkan oleh Rohmah (2018) yang menyatakan bahwa Pelatihan merupakan factor penting dalam sebuah organisasi untuk mencapai tujuan organisasi secara efektif dan efisien. Karena dengan kegiatan Pelatihan bagi organisasi merupakan proses yang sistematis untuk memperoleh dan meningkatkan pengetahuan, ketrampilan, serta mengubah perilaku seseorang atau SDM organisasi dalam jangka waktu yang singkat serta lebih menekankan pada praktek atau teknis, dan bertujuan khusus yang berhubungan dengan jabatan pada organisasinya.

\section{KESIMPULAN}

Berdasarkan hasil penelitian dan pembahasan yang dilakukan, peneliti dapat mengambil kesimpulan sebagai berikut:

1. Pelatihan ekosistem terumbu karang bagi pengelola obyek wisata pantai pandanan sangat urgent dan strategis demi terlaksnanya pelayanan terbaik bagi wisatawan dan lestarinya ekosistem terumbu karang.

2. Meningkatkan kualitas sumberdaya manusia sebagai pelaku kebijakan dalam bidang kepariwisataan melalui jenjang pelatihan perlu di desain secara baik, sehingga dapat menjawab tantangan kebutuhan di masa yang akan datang, khususnya tuntutan menciptakan aparatur yang memiliki keunggulan kompetitif, bersih dan berwibawa, handal serta efektif dan efisien

\section{DAFTAR PUSTAKA}

AB Susanto. 1997. Budaya Perusahaan: Seri Manajemen dan Persaingan Bisnis, PT. Elex. Media Komputindo, Jakarta

Danny Albert Tilon, "Pelatihan Dan Pengembangan Sumber Daya Manusia Pada Restoran A\&W Di City of Tomorrow Surabaya," Agora 1, no. 3 (2013): 1106-1114.

Dessler, Gary. 2015. Manajemen Sumber Daya Manusia. Jakarta: Salemba. Empat.

Edwin B Flippo and Moh Masud, Manajemen Personalia (Erlangga, 1995).

Hadiwijoyo,2012 perencanaan pariwisata berbasis masyarakat (sebuah pendekatan konsep). Graha ilmu : Yogyakarta

Husein Umar. (2008). Metode Penelitian untuk Skripsi dan Tesis Bisnis. Jakarta : PT RajaGrafindo Persada

Kusmayadi dan Endar S, metodologi penelitian dalam bidang pariwisata. Pt gramedia pustaka utama : Jakarta

Neuman, W. Lawrence. 2013. Metodologi Penelitian Sosial Pendekatan Kualitatif dan Kuantitatif Edisi 7. Jakarta: Indeks. 
Pitana, I Gede. 1999. Community management dalam pembangunan pariwisata, analisis pariwisata. Vol.2 no. 2

Rohmah, N.F. 2018. Pelatihan Dan Pengembangan Sumber Daya Manusia. Intizam : Jurnal Manajemen Pendidikan Islam Volume 2, Nomor 1, Oktober 2018 ISSN : 2622-6162 (Online) 2598-8514 (Print)

Sedarmayanti Sedarmayanti and Guke Yolan Safer, "Pengaruh Motivasi Kerja Terhadap Kinerja Guru Sekolah Dasar di Gugus Satu Desa Neglawangi Kecamatan Kertasari Kabupaten Bandung," Jurnal Ilmu Administrasi: Media Pengembangan Ilmu dan Praktek Administrasi 13, no. 3 (2016): 501-524.

Spillane, James.1994. Pariwisata Indonesia, siasat ekonomi dan rekayasa kebudayaan. Yogyakarta: Kanisius.

Setiwan, R.I. 2016. Pengembangan Sumber Daya Manusia di BidangPariwisata: Perspektif Potensi Wisata Daerah Berkembang Jurnal Penelitian Manajemen Terapan (PENATARAN) Vol. 1 No. 1 (2016) hlm. 23-35.

Spillane, James. 1994. Pariwisata Indonesia, Siasat Ekonomi dan Rekayasa. Kebuadayaan. Kanisius. Yogyakarta

Swasono, Agus. (2013) Pengembangan Media Pembelajaran IPS Berbasis Website Untuk Siswa SMP Kelas VIII Pokok Bahasan Pengendalian Sosial. Yogyakarta : Universitas Negeri Yogyakarta

Tjokroaminoto, H. (2010). Islam dan Sosialisme. Bandung: Sega Arsy

Veithzal Rivai Zainal, S. 2015. Manajemen Sumber Daya Manusia Untuk. Perusahaan . Edisike-7. Depok: PT Rajagrafindo 